\section{Canine hookworm: correlation between hematological disorders and serum proteins with coproparasitological results}

\author{
Ancilostomíase canina: correlação entre alterações \\ hematológicas e de proteínas séricas com resultados \\ coproparasitologicos
}

\author{
Diefrey Ribeiro Campos', Livia Reisen Perin², Nayara Campos Camatta², Luanna Castro Oliveira², \\ Daniele Fassina de Siqueira ${ }^{3}$, Karina Preising Aptekmann ${ }^{4}$ \& Isabella Vilhena Freire Martins ${ }^{4 *}$ \\ 'Médico veterinário, Aluno de doutorado. Programa de Pós-graduação em Ciências Veterinária, Universidade Federal Rural do \\ Rio de Janeiro - UFRRJ, Seropédica, RJ, Brasil \\ 2Médicas veterinárias, Alunas de mestrado. Programa de Pós-graduação em Ciências Veterinárias, Universidade Federal do \\ Espírito Santo - UFES, Alegre, ES, Brasil \\ ${ }^{3}$ Médica veterinária autônoma. Serra, ES, Brasil \\ ${ }^{4}$ Médicas veterinárias, Professoras. Departamento de Medicina Veterinária, Universidade Federal do Espírito Santo - UFES, \\ Alegre, ES, Brasil
}

\begin{abstract}
The objective of this study was to correlate the hematologic changes and serum proteins with parasitism by Ancylostoma sp. in dogs. 50 dogs naturally infected with Ancylostoma sp. were used without distinction of sex, from one to six years of age, belonging to the Experimental Chemotherapy Laboratory of Veterinary Parasitology of UFRRJ. Stool samples were collected and these were identified and was carried out egg counts per gram of feces. Also, blood samples were collected for the realization of the complete blood count and levels of total protein, albumin, and globulin. The results were tabulated and submitted to Spearman correlation test with 5\% significance. Of animals evaluated, $42 \%$ showed a reduction in the amounts of red blood cells, hemoglobin and hematocrit consequently were anemic. The eosinophilia was observed in $66 \%$ of evaluated animals and $28 \%$ had hypoalbuminemia. The correlation was found between the parasitism by Ancylostoma sp. and the development of anemia, eosinophilia, and hypoalbuminemia. Therefore, it can be concluded from these results that the parasitism by this nematode causes anemia, eosinophilia, and hypoalbuminemia.
\end{abstract}

Keywords: anemia, Ancylostoma, eosinophilia, hypoalbuminemia.

\section{Resumo}

O objetivo deste trabalho foi de correlacionar as alterações hematológicas e na concentração sérica de proteínas com o parasitismo por Ancylostoma sp. em cães. Foram utilizados 50 cães naturalmente infectados por Ancylostoma sp., sem distinção de sexo, de 1 a 6 anos de idade, pertencentes ao Laboratório de Quimioterapia Experimental em Parasitologia Veterinária da UFRRJ. Foram coletadas amostras de fezes e estas foram identificadas e foi realizada a contagem de ovos por grama de fezes. Também foram coletadas amostras de sangue para a realização do hemograma completo e dosagem de proteína total, albumina e globulina. Os resultados obtidos foram tabulados e submetidos ao teste de correlação de Spearman com 5\% de significância. Dos animais avaliados, 42\% mostram redução nos valores de hemácias, hemoglobina e hematócrito, consequentemente eram anêmicos. A eosinofilia foi observada em 66\% dos animais avaliados e 28\% apresentaram hipoalbuminemia. Foi encontrada correlação entre o parasitismo por Ancylostoma sp. e o desenvolvimento de anemia, eosinofilia e hipoalbuminemia. Portanto, pode se concluir com esses resultados que o parasitismo por esse nematoide causa anemia, eosinofilia e hipoalbuminemia.

Palavras Chave: anemia, Ancylostoma, eosinofilia, hipoalbuminemia.

\section{Introduction}

The hookworms that have importance for dogs are Ancylostoma caninum and A. braziliense. These nematodes are parasites of the small intestine and live fixed in the intestinal mucosa and feed on blood. Each parasite can ingest up to $0.5 \mathrm{~mL}$ of blood per day (Epe, 2009; Traversa, \section{B] M \\ Brazilian Journal of Veterinary Medicine \\ p-ISSN 0100-2430 \\ e-ISSN 2527-2179 \\ ○}

How to cite: Campos, D. R., Perin, L. R., Camatta, N. C., Oliveira, L. C., Siqueira, D. F., Aptekmann, K. P., \& Martins, I. V. F. (2017) Canine hookworm: correlation between hematological disorders and serum proteins with coproparasitological results. Brazilian Journal of Veterinary Medicine, 39(3), 147-151. doi: 10.29374/2527-2179.bjvm019117

Financial Support: Fundação de Apoio à Pesquisa Científica e Tecnológica da Universidade Federal Rural do Rio de Janeiro.

Conflict of interests: No conflict of interests declared concerning the publication of this article.

Received: March 22, 2017.

Accepted: September 12, 2017.

The study was carried out at Universidade Federal Rural do Rio de Janeiro - UFRRJ, Seropédica, RJ, Brasil.

\title{
*Correspondence
}

Isabella Vilhena Freire Martins

Universidade Federal do Espírito Santo - UFES Alto Universitário, s/n, Guararema, CEP 29500-000 - Alegre (ES), Brasil E-mail: ivfmartins@gmail.com

Copyright Campos et al. This is an Open Access article distributed under the terms of the Creative Commons Attribution Non-Commercial License which permits unrestricted non-commercial use, distribution, and reproduction in any medium provided the original work is properly cited. 
2012). Have a cosmopolitan distribution, and Brazil, with prevalence ranging from 45 to $73.7 \%$ (Campos et al., 2016; Farias et al., 1995; Labruna et al., 2006).

Clinical signs resulting from this disease are diarrhea (melena), emesis, abdominal pain, weight loss, increased abdominal volume. These symptoms are dependent on the intensity of parasitism, hookworm species involved and the host resistance. The animals may also have anemia due to laceration caused intestinal mucosa during blood feeding. The species $A$. caninum is the most pathogenic and causes greater blood loss and infection by A. braziliense can occur only hypoalbuminemia (Bowman, 2006; Taylor et al., 2007; Monteiro, 2011).

Puppies are more parasitized by not have an efficient immune response. Severe anemia can occur in adult animals, however, the clinical manifestation may be associated with malnutrition and concomitant chronic diseases. Chronic hookworm may be asymptomatic or only can be observed a small reduction in scores of erythrocytes, hemoglobin, and hematocrit (Robertson \& Thompson, 2002; Travessa, 2012). Another change hematologic that has been reported in dogs parasitized by Ancylostoma sp. is increased number of circulating eosinophils (Nutman, 2007; Silva et al., 2010).

The objective of this study was to correlate the number of eggs per gram of feces of dogs positive for Ancylostoma sp. with hematological disorders and serum concentrations of total and partial proteins.

\section{Material and methods}

The Ethics Committee in the Use of Animals of Federal University Rural of Rio de Janeiro approved the proposed study with protocol number 1888270616.

Were selected 50 dogs, regardless of gender, aged 1 to 6 years, naturally infected with Ancylostoma spp. The animals came from the Kennel of Laboratory of Experimental Chemotherapy in Veterinary Parasitology of Federal University Rural of Rio de Janeiro in Seropédica - RJ. Feces were collected, stored and individually identified with a number of the dogs. For the determination of EPG, samples were coproparasitológica modified McMaster technique (Gordon \& Whitlock, 1939).

Also were collected blood samples by puncturing the cephalic vein with 23G needle and $5 \mathrm{ml}$ syringe. Then the collected blood was transferred to tubes containing the anticoagulant ethylenediaminetetraacetic acid (EDTA) and in tubes without anticoagulant and sent to the clinical laboratory. Were analyzed, red blood cells count, hemoglobin, hematocrit, mean corpuscular volume (MCV) and mean corpuscular hemoglobin concentration (MCHC), white blood cell count, differential leukocyte count, platelet count, total protein, albumin, and globulins.

After conducting all tests, the results were tabulated and statistical analysis used descriptive statistics and the Spearman correlation test, with 5\% significance level, between EPG and hematologic disorders. The data were processed using the Biostat 2009 program (Ayres et al., 2007).

\section{Results}

The results of minimum, maximum, average and standard deviation of evaluated parameters are shown in Table 1.

Animals evaluated in this study, 21 (42\%) had anemia with a decrease in hematocrit, red blood cells, and hemoglobin. Only one animal had the hemoglobin value below normal in isolation, however, this value was very close to the lower limit and there are no other changes in the blood count, so were not consistent with hookworm.

Twenty-six (52\%) dogs had the MCHC values outside the normal range and no alteration in the VCM. Ten of these dogs (38.4\%) had MCHC values below normal in isolation, so there were no other changes in the red series. However, the values were very close to the normal range and were not consistent with any pathology. When anemia was classified, five dogs (23.8\%) had an anemia normocytic normochromic type and 16 (76.2\%) of normocytic hypochromic type.

In the total white blood cell count, 45 (90\%) dogs were within the normal range, four (8\%) were above and one (2\%) was below normal range. There was also no statistically significant difference between the variations in total white blood cell count with OPG animal ( $r s=0.0150, p=0.9176$ ).

In differential white cell count were found some occasional changes, however, were not found statistically significant changes in neutrophil counts $(r=0.1480, p=0.3049)$, lymphocytes 
Table 1. Hematological and biochemical values variations observed in dogs parasitized by Ancylostoma sp.

\begin{tabular}{lccccc}
\hline \multicolumn{1}{c}{ Parameter } & Minimum & Maximum & Avarege & $\begin{array}{c}\text { Standard } \\
\text { Deviation }\end{array}$ & $\begin{array}{c}\text { Reference } \\
\text { Values* }\end{array}$ \\
\hline RBCs (mil/uL) & 4.16 & 7.34 & 5.69 & 0.84 & $5.50-8.50$ \\
Hemoglobin (g/dL) & 9.50 & 17.0 & 12.52 & 1.79 & $12.0-18.0$ \\
Hematocrit $(\%)$ & 30.3 & 50.8 & 39.00 & 5.29 & $37-55$ \\
MCV (fL) & 62.9 & 73.1 & 68.78 & 2.17 & $60-77$ \\
MCHC (\%) & 22.5 & 33.9 & 31.68 & 1.57 & $32-36$ \\
Leucocytes $(\mathrm{mil} / \mu \mathrm{L})$ & 5900 & 19200 & 11866 & 2565.44 & $6000-17000$ \\
Eosinophils $(/ \mu \mathrm{L})$ & 82 & 2880 & 1039.32 & 666.80 & $100-750$ \\
Neutrophils $(/ \mu \mathrm{L})$ & 3515 & 15865 & 7498.70 & 2462.15 & $3000-11400$ \\
Lymphocytes $(/ \mu \mathrm{L})$ & 167 & 6912 & 2736.02 & 1578.66 & $1000-4800$ \\
Monocytes $(/ \mu \mathrm{L})$ & 95 & 1595 & 948.82 & 2768.9 & $150-1350$ \\
Platelets $(\mathrm{mil} / \mu \mathrm{L})$ & 116000 & 554000 & 275380 & 108711.17 & $200000-500000$ \\
Total Proteins $(\mathrm{g} / \mathrm{dL})$ & 4.8 & 7.1 & 6.08 & 0.56 & $5.4-7.5$ \\
Albumin $(\mathrm{g} / \mathrm{dL})$ & 1.5 & 2.6 & 2.13 & 0.28 & $2.0-3.1$ \\
Globulins $(\mathrm{g} / \mathrm{dL})$ & 3.3 & 5.3 & 3.94 & 0.49 & $2.4-4.4$ \\
EPG & 50 & 4150 & 727 & 942.92 & - \\
\hline
\end{tabular}

*Merck Veterinary Manual (Amstutz, 2014).

$(\mathrm{r}=-0.0563 ; \mathrm{p}=0.6977)$ and monocytes $(\mathrm{rs}=0.0691, \mathrm{p}=0.6336)$. It has been described by Dias et al . (2013) to infection by A. caninum can cause an increase in total white blood cell count while A. braziliense to leukopenia. However, these changes were not observed in this study.

However, the eosinophil count, 33 (66\%) dogs presented eosinophilia, so, values above the normal range. Correlation was observed between eosinophilia and EPG $(r=0.4331, p=0.0017)$.

Regarding the platelet count, 32 animals (64\%) had values within the normal range for the species, 15 (30\%) these figures were slightly below normal values and three (6\%) the values were above normal. There was no statistical significance between changes in platelet count with EPG $\operatorname{dogs}(\mathrm{p}=0.1902)$.

Total protein 43 (86\%) dogs were with values within the normal range and seven (14\%) had hypoproteinemia. There was no correlation between the hypoproteinemia and hookworm in dogs ( $r s=-0.0896 ; \mathrm{p}=0.5359$ ).

Regarding the serum protein fractions, 43 animals (86\%) had globulins within the normal range and seven (14\%) had hyperglobulinemia. There was no correlation between hyperglobulinemia and hookworm in dogs (rs = 0.1571, p = 0.2758). Thirty-six (72\%) dogs presented albumin within the reference values for the species, while 14 (28\%) had hypoalbuminemia. Correlation was found between hookworm and development of hypoalbuminemia $(r=-0.5711, p=<0.0001)$.

\section{Discussion}

Anemia observed in dogs can be explained by the blood-sucking habit of these helminths, when adults can ingest up to $0.5 \mathrm{~mL}$ of blood per day (Epe, 2009). These parasites do not live anchored in the same place throughout your life and exchange the feeding site causing several small ulcers in the intestinal mucosa. Bleeding is continued in these lesions because of the anticoagulant molecules present in the saliva of this nematode, a factor that can aggravate the anemia (Christodoulou et al., 2010; Harrison et al., 2001; Harrison et al., 2002).

Most of the animals had anemia normocytic hypochromic type results similar to those found by other authors (Carroll \& Grove 1984; Dias et al., 2013). In severe cases, where the degree of parasitism is intense could also occur the development of hypochromic microcytic anemia 
(Gottstein et al., 1991). Dracz et al. (2014) showed in his study that some animals may also develop hypochromic macrocytic anemia.

The normocytic normochromic anemia can be detected in early cases of bleeding, where there is still not an important stimulus for the regeneration of bone marrow. With the worsening of anemia, it can cause the stimulation of red blood cell production by the bone marrow which can result in a hypochromic macrocytic anemia.

The microcytosis is related to intense parasitism with significant loss of iron. However, it was not observed in the study because that the animals received a ration of good quality which corrects the iron loss caused by the parasite.

Hypoalbuminemia is caused by the blood-sucking habit of the parasite that eats together with the red blood cells and plasmatic albumin. This decrease in albumin is offset values, usually with an increase in the levels of globulins which causes the plasma proteins undergo little change. Authors report that hypoalbuminemia may be the only finding found in parasites animals by A. braziliense (Kalkofen, 1974; Traversa, 2012). In general, the adult dog can develop an immunity able to control the infection Ancylostoma sp., however, it is not capable of eliminating the parasite. Clinical signs and laboratory findings and gravity of disease will be directly related to the intensity of the infection of parasitism. The greater the number of adult parasites in the small intestine more severe will be anemia and hypoalbuminemia. It is worth noting that not always eosinophilia will be present, the increase of the count of this cell type is related to the number of immature forms that are moving the body and not the adult's worms in the intestine.

\section{Conclusion}

Infection for Ancylostoma spp. in dogs are related to the development of anemia, eosinophilia, and hypoalbuminemia in dogs.

\section{References}

Amstutz, H. E. (2014). Manual Merck de Veterinária (3 ed.). São Paulo: Rocca.

Ayres M., Ayres Junior M., Ayres D. L. \& Santos A. S. (2007). BioEstat: aplicações estatísticas nas áreas das ciências biológicas e médicas (5 ed.). Belém: Sociedade Civil Mamirauá.

Bowman, D. D. (2006). Parasitologia Veterinária de Georgis (8 ed.). Barueri: Manole.

Campos, D. R., Oliveira, L. C., Siqueira, D. F., Perin, L. R., Campos, N. C., Aptekmann, K. P., \& Martins, I. V. (2016). Prevalence and risk factors associated with endoparasitosis of dogs and cats in Espírito Santo, Brazil. Acta Parasitologica, 61(3), 544-548. http://dx.doi.org/10.1515/ap-2016-0072. PMid:27447218.

Carroll, S. M., \& Grove, D. I. (1984). Parasitological, hematologic, and immunologic responses in acute and chronic infections of dogs with Ancylostoma ceylanicum: a model of human hookworm infection. The Journal of Infectious Diseases, 150(2), 284-294. http://dx.doi.org/10.1093/infdis/150.2.284. PMid:6470531.

Christodoulou, D. K., Sigounas, D. E., Katsanos, K. H., Dimos, G., \& Tsianos, E. V. (2010). Small bowel parasitosis as cause of obscure gastrointestinal bleeding diagnosed by capsule endoscopy. World Journal of Gastrointestinal Endoscopy, 2(11), 369-371. http://dx.doi.org/10.4253/wjge.v2.i11.369. PMid:21173914.

Dias, S. R., Cunha, D. E., Silva, S. M., Santos, H. A., Fujiwara, R. T., \& Rabelo, E. M. (2013). Evaluation of Parasitological and Immunological Aspects of Acute Infection by Ancylostoma caninum and Ancylostoma braziliense in mixed-Breed Dogs. Parasitology Research, 112(6), 2151-2157. http://dx.doi.org/10.1007/s00436-013-3370-y. PMid:23494155.

Dracz, R. M., Mozzer, L. R., Fujiwara, R. T., \& Lima, W. S. (2014). Parasitological and Hematological Aspects of Co-Infection with Angiostrongylus vasorum and Ancylostoma caninum in Dogs. Veterinary Parasitology, 200(1-2), 111-116. http://dx.doi.org/10.1016/j.vetpar.2013.12.003. PMid:24373514.

Epe, C. (2009). Intestinal nematodes: biology and control. The Veterinary Clinics of North America. Small Animal Practice, 39(6), 1091-1107, vi-vii. http://dx.doi.org/10.1016/j.cvsm.2009.07.002. PMid:19932365.

Farias, N. A., Christovão, M. L., \& Stobbe, N. S. (1995). Frequência de parasitos intestinais em cães (Canisfamiliaris) e gatos (Felis catus domestica) em Araçatuba - São Paulo. Revista Brasileira de Parasitologia Veterinária, 4, 57-60.

Gordon, H. MCL., \& Whitlock, H. V. (1939) A new technique for counting nematode eggs sheep faeces. Journal of Scientific and Industrial Research, 12, 50-52.

Gottstein, B., Ising, S., \& Stoye, M. (1991). Parasitologic, clinical, hematologic and serologic findings in puppies after lactogenic infection with Ancylostoma caninum ERCOLANI 1859 (Ancylostomidae). Journal of Veterinary Medicine, 38(2), 111-122. http://dx.doi.org/10.1111/j.1439-0450.1991.tb00854.x. PMid:1853668.

Harrison, L. M., Córdova, J. L., \& Cappello, M. (2001). Ancylostoma caninum anticoagulant peptide-5: immunolocalization and in vitro neutralization of a major hookworm anti-thrombotic. Molecular and Biochemical Parasitology, 115(1), 101-107. http://dx.doi.org/10.1016/S0166-6851(01)00276-6. PMid:11377744. 
Harrison, L. M., Nerlinger, A., Bungiro, R. D., Córdova, J. L., Kuzmic, P., \& Cappello, M. (2002). Molecular characterization of Ancylostoma inhibitors of coagulation factor Xa. Hookworm anticoagulant activity in vitro predicts parasite bloodfeeding in vivo. The Journal of Biological Chemistry, 277(8), 6223-6229. http:/l dx.doi.org/10.1074/jbc.M109908200. PMid:11741914.

Kalkofen, U. P. (1974). Intestinal trauma resulting from feeding activities of Ancylostoma caninum. The American Journal of Tropical Medicine and Hygiene, 23(6), 1046-1053. http://dx.doi.org/10.4269/ajtmh.1974.23.1046. PMid:4139902.

Labruna, M. B., Pena, H. F. J., Souza, S. L. P., Pinter, A., Silva, J. C. R., Ragozo, A. M. A., \& Gennari, S. M. (2006). Prevalência de endoparasitas em cães da área urbana do município de Monte Negro, Rondônia. Arquivos do Instituto Biológico, 73, 183-193.

Monteiro, S. G. (2011). Parasitologia na Medicina Veterinária (1 ed). São Paulo: Editora Roca.

Nutman, T. B. (2007). Evaluation and differential diagnosis of marked, persistent. Immunology and Allergy Clinics of North America, 27(3), 529-549. http://dx.doi.org/10.1016/j.iac.2007.07.008. PMid:17868863.

Robertson, I. D., \& Thompson, R. C. (2002). Enteric parasitic zoonoses of domesticated dogs and cats. Microbes and Infection, 4(8), 867-873. http://dx.doi.org/10.1016/S1286-4579(02)01607-6. PMid:12270734.

Silva, B. J. A., Freire, I. M. A., Silva, W. B., \& Amarante, E. V. (2010). Avaliação das Alterações Hematológicas nas Infecções por Helmintos e Protozoários em Cães (Canis Lupus Familiaris, Linnaeus, 1758). Neotropical Helminthology, 4, 37-48.

Taylor, M., Coop, B., \& Wall R. L. (2007). Veterinary parasitology (3 ed.). Oxford: Wiley-Blackwell.

Traversa, D. (2012). Pet roundworms and hookworms: a continuing need for global worming. Parasites \& Vectors, 5(1), 91. http://dx.doi.org/10.1186/1756-3305-5-91. PMid:22574783. 